\title{
Salmos e evangelhos por paródias, em poéticas de Luis Augusto Cassas e Murilo Mendes
}

\author{
Eli Brandão Silva* \\ Huerto Eleutério Pereira de Luna**
}

\begin{abstract}
Resumo
O artigo objetiva interpretar, com aportes teóricos e metodológicos de (GENETTE, 1982), (MAINGUENEAU, 1997) e (FIORIN, 1999), paródias do livro dos Salmos e dos Evangelhos, em Deus Mix: Salmos energéticos de açaí com guaraná e Cassis (2001), de Augusto Cassas e Quatro textos evangélicos (1994), de Murilo Mendes.Entende-se que Literatura e Bíblia configuram primordiais, diversas e complexas relações que se prolongam até os dias atuais. Os estudosressaltamdois distintos hipertextos que se configuram como paródias,reescrituras literárias de textos da Bíblia, em dissonância e consonância com a tradição cristã.
\end{abstract}

Palavras-chave: Poesia. Paródia. Salmos. Teologia. Evangelho.

\section{Psalms and gospels by parodies, in poetics by Luis Augusto Cassas and Murilo Mendes}

\begin{abstract}
The article aims to interpret, with theoretical and methodological contributions of (GENETTE, 1982), (MAINGUENEAU, 1997) and (FIORIN, 1999), parodies of the book of Psalms and Gospels, in the poetics of Augusto Cassas and Murilo Mendes, in the works "Deus Mix: Salmos energéticos de açaí com guaraná e Cassis" (2001) and "Quatro textos evangélicos" (1994), by Murilo Mendes. Literature and the Bible are understood to constitute primordial, diverse and complex relationships that extend to the present day. The study highlights both distinct hypertexts that configure parodies, literary rewritings of Bible texts, in dissonance and in keeping with the Christian tradition.

Keywords: Poetry. Parody. Psalms Theology. Gospel.

* Professor do departamento de Letras e Artes da Universidade Estadual da Paraíba. E-mail: elibrandão.uepb@gmail.com

** Professor de Literatura da rede pública do estado da Paraíba; doutorando no PPG em Literatura e Interculturalidade da UEPB.E-mail: huertoluna@yahoo.com.br
\end{abstract}




\title{
Salmos y evangelios por parodias, en poéticas de Luis Augusto y Cassas Murilo Mendes
}

\begin{abstract}
Resumen
El artigo tiene por finalidad interpretar las parodias del libro de los Salmos y de los Evangelios en "Deus mix: Salmos energéticos de açaí com guaraná e Cassis" (2001), de Augusto Cassas y "Quatro textos evangélicos (1994)”, de Murilo Mendes. Para eso, tendremos como base los estudios teóricos y metodológicos de Genette (1982), Maingueneau (1997) y Fiori (1999). Comprendemos que la literatura y la Biblia constituyen primordiales, complejas y variadas relaciones que siguen hasta el presente. Los estudios exaltan dos hipertextosdistintos que se configuran como parodias,traducciones literarias de textos bíblicos, en disonancia y de acuerdo con la tradición cristiana.

Palabras clave: Poesía. Parodia. Salmos. Teología. Evangelio.
\end{abstract}

\section{Introdução}

Consideramos que as relações que se estabelecem entre Literatura ${ }^{1}$ e Bíblia${ }^{2}$ remontam às narrativas míticas dos povos antigos. Desse modo, conjecturamos que entre essas gêmeas univitelinas se estabelecem primordiais, diversas e complexas relações que se estendem até os dias atuais. Consideramos, a partir disso, que essa peculiar configuração literária dos textos da Bíblia foi sendo construída por meio de rico diálogo efetivado com os textos da chamada Literatura Secular,ao longo deprocesso de assimilação cultural e formação das diversas tradições judaicas e cristãs que resultaram nos livros canonizados pela igreja (séculos III e IV). Em consequência da predominante influência da tradição judaico-cristã, por meio da Igreja romana, desde a antiguidade, principalmente, no mundo ocidental, as obras literárias produzidas, ao longo dos séculos, muito recorrentemente estabelecem relaçõesarquitextuais, hipertextuais/intertextuais e interdiscursivas com os textos das "escrituras sagradas", engendrando numerosos palimpsestos.

O modernismo brasileiro, exemplarmente, foi e tem sido palco de muitas e variadasobras, cujas relações construídas se mostram com mais ou menos presença de figuras e temas da tradição cristã, mais ou menos transformação ou imitação

Usarei o termo Literatura para designar o que hoje se consagrou como obra de arte feita com palavras.

2 Embora consideremosa Bíblia como Literatura, o termo será usado neste artigo para nomear o conjunto de textos (judaicos e cristãos) que passaram a ser considerados pela Igreja Cristã, a partir do século III, como "Escrituras Sagradas" em oposição aos textos da chamada "Literatura Secular". 
dos textos e da teologia. É ampla e movediça essa seara, exigindo do analista uma postura lúcida na identificação dessas relações e na interpretação do dinamismo dialógico operada no interior dos textos literários. Cada obra refrata de maneira distinta metáforas, personagens, estruturas poéticas e narrativas do texto bíblico. Essastransposiçõese ressignificações se operam de forma variável, ora em discordância, oraem concordância com as tradições cristãs normativas, em paródiasdos prototextos bíblicos e teológicos.

As obras dos poetas Luis Augusto Cassas e Murilo Mendes se apresentam como amostras desse profícuo diálogo, visto que suas poéticas, cada uma a seu modo, incorporam e refratam os textos bíblicos, reescrevendo-oscriativamente, entre o lúdico e o satírico, o irônico, a crítica humorística; entre o polêmico e o sério, entre a subversão e a profissão de fé. Cassas, em seus poemas de Deus Mix: Salmos energéticos de açaí com guaraná e Cassis, constrói o seu diálogo com a Bíbliapor meio de um viés parodístico, numa reescritura dos Salmos de Davi. Murilo Mendes, em seus poemas de Quatro textos evangélicos, reescreve narrativas bíblicas dos Evangelhos num movimentode transposição estilística mas em parodística séria, em direção à reprodução do discurso teológico da tradição da Igreja. Os dois poetas exemplificam bem a diversidade de reescritura literária hipertextual em diálogo com a Bíblia, pois suas obras exibem resultados opostos.

Estamos diante de duas poéticas que deixam entrever a grande influência exercida pela Bíblia e o dinamismo dos processos de reescritura literária. A tarefa que se nos apresenta exigiu uma hermenêutica de via longa (RICOEUR, 1978), a qual, partindo de uma conjectura compreensiva, conjuga-se a um degrau explicativo de análise da estrutura textual, tendo em vista incluir a abordagem de aspectos discursivos das obras, fechando o ciclointerpretativo com a compreensão como apropriação.

Nosso objeto de estudo é o texto literário, a Literatura em diálogo com a Bíblia. Mas o ponto de partida e de chegada é a Literatura. A Bíblia é tomada aqui como hipotexto, como prototexto teológico, como textualidade e discursividade motivadora da criação dos textos literários. A questão não se esgota com essa primária diferenciação, mas nos coloca num lugar de compreensão de que Bíblia e a Literatura são instâncias discursivas que se misturam e se revelam no hipertexto. 


\section{Bíblia e literatura: caminhos tecidos}

Como nosso objeto de estudo considera um texto dentro de outro, nosso caminho de análise se constrói a partir do conceito de dialogismo (BAKHTIN, 1986), compreendendo que o discurso não se constrói sobre o mesmo, mas se elabora em vista do outro, e de que, portanto, os textos literários, por incorporarem complexamente contributos discursivos autônomos e de proveniência diversa (sociais, políticos, filosóficos, religiosos, teológicos, entre outros), disseminados nos contextos que envolvem a enunciação, caracterizam-se, por excelência, pela sua pluridiscursividade.

Essa dinâmica concepção de texto literário fundamenta fecundas noções da teoria literária contemporânea, entre as quais a Teoria da Transtextualidade (GENETTE, 1982), ou teoria da transcendência textual do texto, visto que se refere a tudo o que coloca um texto em relação manifesta ou secreta com outros textos (GENETTE, 1982, p.7). Genette apresenta cinco modalidades representativas de diálogo transtextual: Intertextualidade: num sentido restritivo, presença literal de um texto noutro: citação; alusão; e estilização; Paratextualidade:relação do texto com os outros que o enquadram, como títulos, subtítulos, prefácios, posfácios, avisos, que funcionam como integradores do texto num dado contexto, chave hermenêutica e exercem funções semântico-pragmáticas; Metatextualidade: relação que une um texto a outro, por meio de texto acerca de outro, sem necessariamente citá-lo. Tipicamente, a crítica, a análise literária, o comentário, embora não seja incomum aparecer, complexamente, no seio da literatura; Hipertextualidade: toda relação que une um texto B (Hipertexto) e um texto A (Hipotexto), por meio de dois processos: transformação e imitação. A transformação se mostra como ampliação, redução ou substituição do texto com o qual se relaciona, exemplarmente, certos gêneros canônicos como o pastiche, a paródia, entre outros; Arquitextualidade: relação mais abstrata e implícita, classificação literária, relações do texto com normas, propriedades, que podem ser identificadas em três níveis: a) modos do discurso, b) gêneros literários, c) subgêneros do romance.

Em nosso estudo, vamos nos concentrar sobre as relações hipertextuais, mais particularmente, a paródia. Entendemos, na esteira de Genette (1982), que o hipertexto é, por excelência, um palimpsesto, literalmente, pergaminho do qual a inscrição anterior foi apagada para que outra a substituísse. Tal operação, entretanto, não conseguiu apagar irremediavelmente o anterior, pois um texto sempre 
pode camuflar outro sem que, contudo, o dissimule completamente, de modo que o mais antigo pode ainda ser lido no atual como por transparência.

É preciso, salientar, entretanto, que as diversas modalidades de relações entre os textos apontados por Genette não são exclusivas, mas antes expressam os traços predominantes. Um metatexto, de certa maneira,configura-se com alguma semelhança com o hipertexto, sendo que este quase sempre possui intertextos; alguns paratextosse configuram como um pequeno metatexto,deixando entrever, por vezes, possíveis relações arquitextuais ou a hipertextualidade do texto. E o hipertexto, muitas vezes apresentado por indicações paratextuais, representa sempre transformação ou imitação arquitextual, eventualmente convocando intertextos.

As obras se apresentam mais explicitamente hipertextuais do que outras, ora por meio de contrato explícito de imitação burlesca, ora implícito e alusivo, alertando o leitor sobre provável relação entre uma obra e outra. Quanto menos compacta e evidente se mostrar a hipertextualidade, tanto mais a sua análise depende de julgamento interpretativo do leitor.

Entre as relações hipertextuais, concentraremos nosso foco na paródia, visto ser essa uma modalidade presente nos poemas selecionados. Entendemos, na esteira de Genette (2010, p. 39) a paródia como "o desvio de texto pela transformação mínima".A paródia tem sido entendida, por um critério funcional, numa acepção mais consagrada, como uma relação burlesca entre dois ou mais textos. Entretanto, apoiados nos estudos de Genette em Palimpsestos (2010), considerando o critério estruturalcomo central, embora sem desprezar por completo o funcional, entendemos a paródia (cantar ao lado) num sentido burlesco e carnavalizante (quando o canto ao lado é para se contrapor ao outro; mas também num sentido mais harmônico, "paródia séria" (p. 40), quando o canto ao lado é para homenagear.Além disso, outro motivo para usarmos, neste trabalho, o termo paródia relaciona-se ao que dizia o próprio Mendes, quando observava que "os poemas são paródias da poesia, como os sermões são paródias do Verbo" (MENDES, 1995, p. 844).

Utilizaremos também em nossa análise o conceito, também filiado ao Dialogismo bakhtiniano, de Interdiscursividade, por meio do qual podemos dizer que:sempre que há alguma relação transtextual, há interdiscursividade, pois, o enunciador, necessariamente, se refere ao discurso que o texto manifesta. O inverso, porém, não é verdadeiro, pois pode haver interdiscursividade sem haver 
intertextualidade [ou transtextualidade] (FIORIN, 1999, p. 30-35). Oprocesso interdiscursivo ocorre quando se incorporam temas e/ou figuras, percursos temáticos e/ou figurativos de um discurso em outro. Todo discurso define sua identidade em relação ao outro, constituindo, assim, uma heterogeneidade constitutiva, revelando, por um lado sua identidade e, por outro, sua diferença, como observa Maingueneau (p. 1997, 116). De modo que o interdiscurso deve ser entendido como um processo de reconfiguração incessante no qual uma formação discursiva é levada a incorporar elementos pré-construídos, produzidos fora dela, com eles provocando sua redefinição e redirecionamento, suscitando, igualmente, o chamamento de seus próprios elementos para organizar sua repetição, mas também provocando, eventualmente, o apagamento, o esquecimento ou mesmo a denegação de determinados elementos.

O engendramento dos elementos teóricos e metodológicos apresentados, tendo em vista a análise dos poemas-paródias, configura caminho compatível com complexa e híbrida natureza do objeto, numa abordagem que chamamos hermenêutica hipertextual.

O diálogo entre Literatura e Bíblia não se apresenta, como vimos,como uma tentativa de conciliar textos tão distintos. Talvez seja a busca pela compreensão de que, ambas, têm em comum a configuração metafórica e a carga simbólica em seus textos. Trata-se também de diálogo que tem uma longa história:

Ao longo da história da literatura encontramos abundante presença de "textos sagrados" no seio de textos literários, num diálogo intertextual e/ou interdiscursivo incessante, num processo que configura relações de concordância ou discordância, configurando, muitas vezes, intrigantes teologias. A literatura, além de estar intimamente ligada à religião desde suas origens, prossegue sendo sua reescritora, influenciando, por isso mesmo, não só na manutenção de ideologias alienadoras mas também forjando teologias da libertação do humano, portanto, teologias ortodoxas e teologias heterodoxas (BRANDÃO, 2007, p. 19,20).

Partimos da compreensão de que o texto literário é possuidor de uma natureza dialógica e pluridiscursiva. A obra literária não é uma realidade ensimesmada, antes de tudo, ao se constituir, ela convoca outros textos e discursos, transformando-os. Isto porque ela não é uma realidade fechada em si, ao contrário, dentro dela ecoam outras vozes, outros saberes, outros discursos que constituem uma unidade polifônica. 
É a partir dessa compreensão da obra literária que se abrem possibilidades de diálogo entre a Bíblia e a Literatura, bem como, o entendimento de como se estabelece esse diálogo no interior dos textos literários. Os Salmos do Deus Mix, de um modo geral, estabelecem múltiplas e complexas relações com os Salmos da Bíblia, mas também com vários textos da Bíblia, da filosofia e da cultura popular. Percebe-se, de imediato, que o paratexto principal, o título, nos remete ao livro da Bíblia. Essa indicação paratextual já nos encaminha para a possibilidade de estarmos diante de um hipertexto, que toma como seu hipotexto os Salmos de Davi. Além disso, o hipertexto, ao se inscrever parodiando, convoca a arquitextualidade do outro texto, seja refletindo-a ou refratando-a.

Do mesmo modo, se dá em Murilo Mendes, já a partir do paratexto da obra convoca-se a referência à Bíblia: Quatro textos evangélicos. O título já se enuncia como paródia de um texto já existente: os evangelhos. A poética de Murilo Mendes, diferente da Cassas, parte de um princípio confessional para elaboração de sua poesia a partir dos textos bíblicos, seu valor, para além de uma mera reprodução de um convertido, situa-se no âmbito da reinvenção da linguagem bíblica e de como se pode, a partir de sua leitura dos evangelhos, recriar narrativas bíblicas tradicionalmente cristalizadas no cânon teológico e na tradição da igreja.

\section{Cassas e a reescritura parodística da Bíblia}

-"Sou Davi, pai de Salomão [...]

-Fui bíblico. Celebrei Deus e o Homem belos cantos devocionais. Mas esqueci-me de celebrar o Mundo. Redime as minhas noites de alcatraz. Canta Deus, o Homem e o Mundo. Sê tríblico e tua voa será ouvida no Monte Sinai. Deus recompensará em dobro os teus direitos autorais"(CASSAS, 2001).

A obra de Luís Augusto Cassas, ${ }^{3}$ "cuja poética caleidoscópica, estranha e delirantemente visionária se tem constituído como um dos mais bem realizados projetos literários de nossa lírica contemporânea" (SILVA,2002, p.21), num esforço por traduzir metaforicamente dilemas e inquietações do homem contemporâneo,

\footnotetext{
Poeta maranhense, contemporâneo, autor de diversos livros, entre eles, "Shopping de Deus \& A Alma do Negócio", 1988, "Retorno da Aura", 1994, "Liturgia da Paixão", 1997, "Ópera Barroca", 1998, "Bhagavad-Brita" (a canção do beco), 1999, Evangelho dos Peixes para a ceia de Aquário, 2008, Tao à Milanesa, 2012.
} 
em face de profundas e complexas transformações científicas, tecnológicas e socioculturais, num contexto de dessacralização do mundo e de mercantilização do sagrado. Em seu projeto poético, Cassas criativamente convoca e complexamente escreve obras que dialogam transtextualmente e interdiscursivamente com textos mitopoéticos, teológicos e filosóficos de diversas culturas, por meio de multifacetada teia de procedimentos e concepções estético-filosóficas, engendrando, no dizer de Silva (2002, p. 21),

...universal e transdialeticamente, uma espécie de síntese cosmogônica de tudo, atravessada por uma visceralmente dramática compreensão do universo, através de um vertical incursionamento pelas camadas mais abissais da sua mais significativa e errante personagem histórica: o homem, com os seus desafiadores enigmas e encantatórios sortilégios.

Em Deus Mix: salmos energéticos de açaí com guaraná e Cassis, o autor conta que a ideia da obra surgiu de sugestão dada pelo rei Davi, por meio de sonho, no qual lhe incumbiu de escrever salmos que celebrassem a relação Deus-homem-mundo, já que os Salmos da Bíblia celebravam a relação Deus-homem. Trata-se, portanto, como sugere o paratexto principal, de um palimpsesto dos Salmos da Bíblia, que configura "estésicas fronteiras entre o lúdico-epifânico e o profético-apocalíptico" (SILVA, 2002, p. 21).

Nos salmos bíblicos, Deus aparece representado tanto em figuras do Deus como pai protetor, guia misericordioso, como também vingativo e chefe dos exércitos. Por sua vez, o homem aparece diante desse Deus com fé, obediência, temor, contrição, alegria ou lamentação. Nos Salmos de Cassas, o homem do mundo moderno continua com os mesmos sentimentos, buscando deuses poderosos e providentes, que resolvam prioritariamente suas questões do imediato. Entretanto, como são outros tempos e outras relações entre homem, coisa e sagrado, os salmos de Cassas celebram um Deus Mix, que se apresenta muitas vezes em concorrência imagética e mercadológica com os Polishops ou os BigMacsda vida, configurando novas figuras dos deuses.

Os Salmos do Deus Mix, de um modo geral, estabelecem múltiplas e complexas relações com os Salmos da Bíblia, mas também com vários textos da Bíblia, da filosofia e da cultura popular. Percebe-se, de imediato, que o paratexto principal, o título, nos remete ao livro da Bíblia. Essa indicação paratextual já nos encaminha para a possibilidade de estarmos diante de um hipertexto, que toma como seu hipotexto os Salmos de Davi. Além disso, o hipertexto, ao se 
inscrever parodiando, convoca a arquitextualidade do outro texto, seja refletindo-a ou refratando-a.

Identificamos que entre os salmos de Cassas e os Salmos da Bíblia se estabelece, num plano macrotextual, uma arquitextualidade, a qual evidencia, num plano mais superficial, o gênero poético, mas, para além disso, há uma apropriação da estrutura do subgênerosalmítico e um produtivo diálogo transtextual e interdiscursivo.

Selecionamos aqui alguns poemas da obra de Cassas, para breves considerações analíticas.

\section{Salmo salvador}

cantai ao açaí

um canto novo

pois revelou prodígios

muito mais que o ovo

salvando em rodízio

a fome que assa aí

cantai ao açaí

um canto glamoroso

pois deu poder e alívio

ao tesão do povo...

cantai ao açaí

com tuba e trator!

eis que a casa de Davi

tem novo protetor

\section{Novo salmo do açaí}

cantai ao açaí

um canto forte

salvou-nos do piti

e o sabor da morte

desterrou-nos babilônia

livrou-nos da maçã

e a acidez malsã

redimiu o castigo

do fruto proibido

limpou-nos a aura

lavou-nos a honra

aleluia! aleluia!

em copo, taça ou cuia 
Analisando os poemas SALMO SALVADOR e NOVO SALMO DO AÇAÍ, identificamos que ambos tematizam o açaí em analogia a Deus. Percebemos não só a indicação paratextual, indicando a presença patente dos intertextos bíblicos dos Salmos 96, 98 e 149, "cantai ao senhor um cântico novo", introito e estribilho do poema, mas também ouvimos o eco de sua musicalidade, o cadenciamento, a versificação, aspectos de sua arquitextualidade. Todas essas identidades são contrastadas pelas diferenças promovidas pela lírica dos Salmos de Cassas. Os dois poemas trazem o tema do louvor renovado e dirigem a Deus, mas o deus aqui louvado é o deus do açaí. ${ }^{4} \mathrm{O}$ deus do açaí merece um "canto novo" "um canto glamoroso", "forte", com acompanhamento de vários instrumentos musicais. Isto porque o deus do açaí é, interdiscursivamente, salvador, libertador, purificador e protetor. Pela metaforização dos poderes e efeitos do açaí, os sentidos dos predicativos divinos do açaí se expandem, pluridiscursivamente, e se efetivam como ação resolutiva dos problemas existenciais e materiais do cotidiano, a saber, saciam a fome, aumentam o tesão e protegem meu lar, curam o histerismo, livram da tentação e da morte, redimem do pecado original e purificam o espírito.

\section{Salmo sem graça}

Por tudo dai graças
pelo poder e sua farsa
pela dor e a argamassa
pela desonra que trapaça
pela fé tornada fraca
pelo ódio e a carapaça
por tudo dai graças
até mesmo às traças
(e às insones baratas)
essas humildes comparsas
do mistério da graça.

O SALMO SEM GRAÇA convoca intertexto da1ª Epístola de Paulo aos tessalonicenses, no capítulo 5 , versículo 18 , desenvolvendo a temática teológica da graça, paratextualmente indicada. O poema transporta arquitextualmente o gênero salmítico e hipertextualmente os Salmos de Davi. Do modo como a questão se apresenta no poema, levantam-se questões polêmicas, que interdiscursivamente

4 Fruta energética, à semelhança do guaraná, típica do Maranhão. 
remetem para uma complexa paródia. Isto porque, ao tempo em que parodia um salmo de gratidão, parodia-o justamente, a partir de estrato de exortação paulina, "Em tudo, dai graças". O efeito do sentido metaforizado se intensifica porque o eu-lírico do poema, tomando por base a exortação referente ao dever de tudo agradecer, toma o sentido do pronome indefinido em máxima potencialização discursiva. Desse modo, agradecer por tudo não deixa nada de fora. Seguindo esse caminho, a recomendação do eu-lírico é dar graça pelos poderosos e suas farsas, pelo sofrimento e pelo trabalhador explorado, pela humilhação e traição, pela fraqueza da fé, o ódio e pelos ínfimos insetos, pois eles guardam o mistério da graça.

Esse processo expressa uma parodização do texto de 1Tessalonicenses, em que a exortação deixa entrever certa crítica à teologia da gratidão, a qual assume um caráter cômico. Em Cassas, embora, em alguns poemas, a paródia apareça com traços de carnavalização, ela nunca é o grotesco em si, mas sempre revela, pela metaforização, sentidos de crítica que reverberam teologias construídas no cotidiano das pessoas.

A limitação de espaço nos impede de apresentar outros poemas, como Salmo do verdadeiro mandamento, Salmo imobiliário, Salmo de farmácia, Salmo capital, Salmo mercantil, Salmo devedor, Salmo FastFood, Salmo Self Service, entre outros. Pelos títulos, já fica a indicação de que há um processo de hirpertextualizaçãoparodística em curso.

Concluímos destacando que a obra Deus Mix configura um palimpsesto, no qual se estabelecem relações dialógicas, transtextuais e interdiscursivas, por meio das quais a dinâmica do processo metafórico da poesia potencializa sentidos que, implicitamente, apontam para uma espécie de crítica humorística ao próprio texto bíblico, mas também às teologias e práticas de alguns grupos de cristãos, cuja religião ficou refém do mercado e da teologia da prosperidade.

\section{Murilo Mendes: entre transposição inventiva e confissão religiosa}

A poesia de Murilo Mendes se prefigura entre as mais importantes do Modernismo brasileiro, símbolo de síntese e invenção dos ideários modernos, sua literatura carrega o traço do experimentalismo e da fixação na tradição, um paradoxo à primeira vista, mas que se desfaz, quando percebemos que a tradição está na sua poesia para ser transmutada em outra e nova significação. Nesse sentido, quando pensamos na sua relação com o catolicismo, estamos diante de uma 
tensão que mostra as duas facetas de sua poesia, de um lado uma obra que se propõe restaurar imagens perdidas da tradição cristã católica e ao mesmo tempo, de outro lado, a poesia subverte essa conversão instaurando novos sentidos às imagens, narrativas e textos do imaginário católico, e, mais especificamente, dos textos evangélicos, em os Quatro textos evangélicos, de 1956.

A literatura de Murilo Mendes se insere nessa filiação da literatura brasileira, está preocupada em recriar a relação do homem a partir de sua relação com o divino, com o infinito, com o absolutamente Outro. A poesia vem a ser a via pela qual se materializa a vontade divina e seu modo de diálogo com Deus, posição essa tecida junto a Jorge de Lima que, juntos, propuseram: "Restauremos a poesia em Cristo" (LIMA, 1997, p. 320). Mas também, ainda que de forma indireta, com Manuel Bandeira: "Estás em tudo que penso" (BANDEIRA, 1993, p. 183), Carlos Drummond de Andrade: "Meu Deus, por que me abandonastes/ se sabias que eu não era Deus/ se sabias que era eu era fraco" (ANDRADE, 2006, p. 21) e João Guimarães Rosa, que sentenciou: "Deus esteja” (ROSA, 1986, p. 4). Todos esses autores, expoentes do modernismo brasileiro, trazem a marca do diálogo com Deus, seja para afirmá-Lo, seja para negá-Lo, seja para questioná-Lo.

É importante adentrarmos nessa relação entre conversão e poesia na obra de Murilo Mendes, pontuando que esta é uma de suas características que o fixa como um dos representantes mais significativos do modernismo brasileiro, ainda que essa relação entre modernismo e religião seja incipiente e quase inexplorada nos estudos sobre essa fase da poesia brasileira. O crítico Murilo Marcondes de Moura, em posfácio à última antologia do poeta publicada no Brasil, em 2014, pela extinta Cosac Naify, assevera:

A obra de Murilo Mendes (1901-1975 pode ser lida em consonância com a poesia brasileira de seu tempo. Os seus livros iniciais, Poemas e o Visionário, escritos entre 1925 e 1933, apresentam evidentes pontos de contato com a poesia modernista, sobretudo pelo humor sarcástico e pela linguagem desabusada. Traços comuns a Manuel Bandeira, Mário e Oswald de Andrade, especialmente a Drummond, seu contemporâneo exato, são perceptíveis. A conversão religiosa que se seguiu alterou muita coisa, mas não retirou o poeta desse âmbito estético de extração modernista: o diálogo com Jorge de Lima, por exemplo, conduziria ambos não ao afastamento, mas antes ao aprofundamento de procedimentos vanguardistas, como o da fotomontagem (MOURA, 2014, p. 262). 
A tradição modernista ecatólica na obra de Murilo Mendes, que em parte ele foi seu criador também, é, em termos temáticos e estilísticos, o ponto de partida para compreensão, em globalidade, de sua poesia. A filiação a essa tradição não estabiliza sua obra em um lugar de reprodução de dogmas cristalizados, pois, como manifestam seus versos: "Deus não formou uma só pessoa que o possa compreender: este é um privilégio de sua natureza” (MENDES, 1994, p. 1.456), ele passa a desautorizar, até certo ponto, a interpretação dogmática e unívoca da instituição religiosa na qual professa sua conversão, colocando a poesia como lugar de entendimento do divino, reatualizando e recriando o universo bíblico que irá reinterpretar e reescrever. Sua poesia potencializa questões que ficaram apenas no limiar de alguns autores do modernismo brasileiro ou desdobra questões já abordadas por nomes como Carlos Drummond de Andrade, Manoel Bandeira e Jorge de Lima, autores com quem estava em constante diálogo.

O crítico Murilo Marcondes de Moura enfatiza o caráter bricolar que a poesia de Murilo Mendes adota ao situar-se num espaço de confissão e conversão, pois, ao inserir-se no imaginário católico, concomitante ao processo vanguardista de fotomontagem na composição, abria-se com isso um leque de possibilidades inventivas, que, ao primeiro passo pode parecer poesia panfletária de poeta convertido, mas que se desdobra surpreendentemente como lugar de recriação e burlagem de mitos cristãos e versões bíblicas canonizadas.

A obra Quatro textos Evangélicosestá disposta em quatro longos poemas, que são: O paralitico de Betsaida, As núpcias de Caná, O Cristo aclamado e Judas Iscariotes, ambos poemas são, respectivamente, uma reescritura das passagens dos evangelhos de Mateus cap. 9, Marcos cap. 2, Lucas cap. 5, João cap. 5, nas passagens alusivas à cura do paralítico nas águas de Betsaida; João cap. 2, referente às bodas de Caná da Galileia e ao milagre da transformação da água em vinho; Mateus cap. 21, Marcus cap. 11, Lucas cap. 19, João cap. 12, quando tratam da entrada de Jesus em Jerusalém e o discurso do senhorio de Cristo; Mateus cap. 26, Marcos cap. 14, Lucas cap. 22, João cap. 13, sobre a traição de Judas e o destino do apóstolo traidor. Vale observar que na obra de Mendes os poemas estão dispostos na mesma ordem que aparecem nos quatro evangelhos, demonstrando, já a partir da organização e disposição dos poemas na obra, uma fiel simetria como quatro evangelhos da Bíblia.

Em termos arquitextuais, os quatro poemas não seguem a estrutura do texto 
bíblico. Estão dispostos em estrofes de versos decassílabos e brancos. O conjunto de cada estrofe reúne número irregular de versos de uma estrofe para outra, não obedecendo a uma estruturação fixa, variam em estrofes de dois a 12 versos. Nesse sentido, difere de Cassas, que reproduz a mesma arquitextualidade do texto salmítico, enquanto Murilo Mendes busca uma textualidade que em nada remete à arquitetura do texto bíblico, dando um tratamento à linguagem de forma que esta renomeie a narrativa bíblica numa dicção modernista, utilizando de recursos estilísticos contemporâneos para tratar de narrativas arquetípicas da tradição cristã.

O primeiro poema de Quatro textos evangélicos, O paralítico de Betsaida, está nesse lugar de abertura do livro, na mesma posição que o texto evangélico está na Bíblia em relação aos textos posteriores sobre as bodas de Canaã, a entrada triunfal de Jesus em Jerusalém e a traição de judas. Nesse sentido, de forma macro, na disposição dos textos na obra, obedece à mesma arquitetura do texto bíblico, trazendo a mesma ordem das narrativas evangélicas na Bíblia. Os hipotextos bíblicos motivam os hipertextos poéticos, mas esse contágio e transfiguração acontecem em dois planos: interdiscursivo e intertextual, que são postos no corpo do poema ao trazer as figuras e imagens do texto bíblico de modo interdiscursivo e intertextualmente ao citar passagens dos evangelhos de forma literal, num movimento de bricolagem de falas, personagens e descrições do universo discursivo e textual da Bíblia.

Em O paralítico de Betsaida, a abertura do poema da mesma forma que no evangelho, transmigraa mesma sequência de ações e o mesmo encadeamento de imagens:

Em torno da piscina de Betsaida

Cinco pórticos levantam suas colunas, Jazem ali cegos, estropiados e paralíticos, Aguardando o movimento circular da água:

Em certo momento um mensageiro do Senhor

Por sua mão invisível

Ordena à água inerte se mover;

O espírito de Deus soprando nela

Confere-lhe sua antiga virtude

E os corpos são curados

(MENDES, 1994, p. 791). 
Por sua vez, o texto bíblico narra:

Depois disso, por ocasião de uma festa dos judeus, Jesus subiu a Jerusalém, junto à Porta das Ovelhas, numa piscina que, em hebraico, se chama Bethzata, com cinco pórticos. Sob esses pórticos, deitados pelo chão, numerosos doentes, cegos, coxos e paralíticos ficavam esperando o borbulhar da água. Porque o anjo dos Senhor se lavava, de vez em quando, na piscina e agitava a água; o primeiro, então, que aí entrasse, depois que a água fora agitada, ficava curado, qualquer que fosse a doença (BÍBLIA SAGRADA, p. 1.853).

O poema se perfaz como uma reescriturasímile do texto do Evangelho de João, capítulo 5, versículos 1-18, numa quase intertextualidade citativa literal com o hipotexto joanino. O que nos faz entender, fora a referência autoral do poema, que não se trata de uma citação direta do texto bíblico, é a disposição em versos e a supressão de alguns termos e estruturas sintáticas na ordem da frase, no restante, o poeta organiza seu poema com a repetição direta dos fatos, imagens e personagens do texto bíblico. Quando se trata da relação entre a Bíblia e a poesia de Murilo Mendes, esse é um procedimento recorrente nos seus poemas, em específico, na obra Quatro textos Evangélicos. O que vai colocar sua poesia numa relação reinventiva com a Bíblia, será a construção de um discurso interpretativo sobre os fatos bíblicos dentro do próprio corpo do poema, nesse em que se está narrando, como numa forma de adaptação, as próprias narrativas bíblicas agora desdobradas com a sutil interpretação pessoal do poeta, como vemos no arremate final do poema $O$ paralitico de Betsaida:

Como o Cristo cura ainda no sábado, Os burocratas, servos da lei e da aparência, Não podem suportar a transgressão E planejam entre si crucificá-lo.

Seu verbo gerado desde toda eternidade, Idêntico ao do Pai, levanta os mortos: Alpha e Ômega de todos que nascem, É o santo sacramento do Universo (MENDES, 1994, p. 794).

Todo o poema segue a mesma sequência de fatos do texto evangélico, da descrição do lugar de Betsaida à concretização do milagre operado por Cristo. O texto acaba se tornando, em linhas gerais, uma adaptação em versos livre do 
evangelho, em muito pouco transgride, em níveis textuais e discursivo, o texto bíblico. Observemos que, apenas nos versos finais, o poema evoca uma voz pessoal, distante da voz do narrador evangélico da Bíblia, tecendo uma espécie de panegírico ao Cristo que operara o milagre de fazer o coxo andar, e reafirma a interpretação teológica cristã da filiação direta de Jesus ao Pai, sendo o Cristo a reencarnação de Deus Criador, princípio e fim do universo.

Em As núpcias de Caná, segundo poema, se apresentará o conhecido episódio do evangelho de João, capítulo 2, versículos 1-12, onde Jesus opera seu primeiro milagre e transforma a água em vinho. De modo diferente do poema de abertura, $O$ paralítico de Betsaida, este não visa uma fiel reprodução do episódio bíblico, pois o milagre da água transformada em vinho fica em segundo plano e o elogio ao amor esponsal ganha a centralidade da narração poética.

Em níveis intertextuais o poema funde dois textos bíblicos distintos, o evangelho de João e o poema erótico de Cântico dos Cânticos, atribuído a Salomão. Assim como no texto do Antigo Testamento, o poema obedece ao turno de voz, dividido entre Esposo e Esposa, citando de forma literal e em aspas o poema bíblico:

O esposo:

"Quem é esta que sobe do deserto como colunas de fumo, Perfumada de mirra e de incenso?

És toda formosa, amada minha, Senhora e escrava minha,

E em ti não há falha nem sinal de homem.

(...)"

A esposa:

"Eu sou o narciso de Saaron,

Uma açucena dos vales de Engadí.

Morena sou, já que o sol mirou-se”

(MENDES, 1994, p. 798).

O poema traz o episódio bíblico da festa de Caná da Galileia, mas o milagre do vinho perde a centralidade como, costumeiramente, é posta sobre esse milagre operado por Jesus e o casamento passa a ocupar, no poema, o centro da narração. O episódio das bodas, agora é acrescido com o texto poético dos Cantares de Salomão, o que opera uma transgressão do texto evangélico de João que não 
remete em momento algum ao cântico. O poema opera, assim, uma dupla reescritura da Bíblia deixando entrever o aspecto intertextual da obra. Seguindo o mesmo procedimento do poema anterior, pouco se vê da voz pessoal do poeta, extinguindo-se, raros momentos em que se insere uma interpretação sobre os textos bíblicos, até então, apenas adaptados em versos:

O esposo e a esposa despem as vestes. Fundem-se.

O universo é reduzido e adaptado

Às dimensões do meu quarto nupcial

(MENDES, 1994, p. 799).

A conotação erótica, inexistente no texto evangélico, ganha aqui contornos bem definidos e explícitos, o que subverte a ordem das coisas e instaura uma nova interpretação sobre o episódio de Caná. É nesse aspecto que a poesia de Murilo Mendes ultrapassa a possível fixação num lugar de mera reprodutora e adaptadora dos textos bíblicos. O rompimento com a tradição é sutil e quase imperceptível, tendo em vista a insistência em manter uma fidelidade ao texto bíblico e às concepções cristãs.

O terceiro poema, O Cristo aclamado, rememora o episódio da vida de Cristo, dias antes de sua crucifixão, presente nos evangelhos de Mateus, Marcos, Lucas e João. Todo o poema segue o mesmo procedimento dos anteriores, reescrevendo de forma quase literal o texto bíblico, agora disposto em versos. Esse poema é emblemático no conjunto da obra de Murilo Mendes, pois sintetiza o projeto poético de sua conversão: "restauremos a poesia em Cristo". Premissa que posteriormente foi revista pelo próprio poeta ${ }^{5}$ na revisão de sua obra, em texto publicado sob o título "A poesia de nosso tempo", na ocasião de sua reunião de poesia, em 1959, 25 anos depois da publicação da poesia manifesto Tempo e eternidade, de 1934, em coautoria com Jorge de Lima.

O Cristo aclamadose serve do acontecimento bíblico da entrada de Cristo em Jerusalém e de toda significação escatológica que esse episódio evoca para concretizar seu projeto poético de recuperar a poesia na pessoa de Cristo, seguindo o mesmo parâmetro da interpretação teológica cristã da encarnação de Cristo como redentora de nossa natureza decaída. O senhorio de Cristo é posto no centro do poema que reivindica esse reconhecimento pelos homens ainda não despertos da cegueira dos ídolos falsos:

5 "De Tempo e eternidade, cancelei a inscrição primitiva "Restauremos a poesia em Cristo", por desnecessária atualmente" (MENDES, 2014, p. 253). 
Ó povo dos séculos posteriores, cegaste.

Não divisas que este é o único Rei perene?

Por que incensas o ídolo da verdade transitória

$\mathrm{E}$ te ajoelhas ante falsos reis e ditadores?

Rejubila-te, povo de Jerusalém, Amplia tua visão do Príncipe da paz,

A quem dedicas o ramo de oliveira

Trazido pela pomba desde o tempo do dilúvio.

Conhecendo teu Deus conhecerás a ti mesma, Jerusalém, Jerusalém

(MENDES, 1994, p. 802).

Aqui, a figura de Cristo ganha a centralidade e a significação última que a poesia de Murilo Mendes passa a perseguir. Todas as coisas, antes sem sentido e, até mesmo a crise da linguagem que provocara o esvaziamento de sentido e referência do signo linguístico, passa agora a ter significação na ação salvífica de Cristo, no qual se redime a existência de todas as coisas: "Será crucificado e ressuscitará/ atraindo todas as coisas a si mesmo" (MENDES, 1994, p. 803). Percebemos aqui uma clara adesão e confissão à interpretação cristã da figura de Jesus. O poema convoca o texto bíblico para reafirmar uma verdade teológica instituída, agora não mais se servindo do discurso teológico em si, mas do dispositivo poético para endossar uma visão já existente, agora diluída em sua concepção de poesia restaurada em Cristo.

O último poema, Judas Iscariotes, rememora os episódios da vida e morte do apóstolo traidor, figura paradoxal na mítica bíblica, assim como Caim no Antigo Testamento. O poema se desenvolve na descrição dos fatos bíblicos, em nada avançando na transformação do hipotexto bíblico, segue o mesmo encadeamento de imagens e disposição da ação narrativa já presentes nos textos evangélicos de origem. Põe em solução simplista e maniqueísta a figura do apóstolo que entrega Jesus aos doutores da Lei, sendo fiel à interpretação teológica ortodoxa.

Porém, ao colocar no mesmo horizonte a questão sobre o bem e o mal que a postura de Judas evoca, o poema se abre a uma tensão e conflito com a própria interpretação teológica que julga confessar:

Ninguém jamais saberia definir

Qual a parte de Deus e a parte do demônio

Nessa justaposição de duas faces adversas.

Judas Iscariotes, criado a semelhança de Deus, 
Entrega a Segunda Pessoa da Santíssima Trindade

Ao clero israelita,

Ao poder romano, ao magistrado e a polícia.

E com Ele nós todos traímos o Senhor

(MENDES, 1994, p. 808).

Escapa da solução maniqueísta e cai-se no terreno do insolúvel, ainda que de maneira ligeira, ao questionar-se qual a parte de Deus nisso tudo. O que demonstra uma fuga da poesia de Murilo Mendes da pura confissão e profissão a uma verdade de fé em que se diz convertido. A figura bíblica de Judas desestabiliza uma fé que se julga inabalável e que não se questiona diante dos paradoxos da ação divina, ao conceber o livre-arbítrio ao homem, aqui, dramaticamente tensionado na traição de Judas. O final do poema se encaminhapara esse lugar de reafirmação de fé, solucionando simplisticamente o problema do mal contido na figura do apóstolo proscrito ao culpar o homem de uma escolha que lhe parecia inevitável para que se cumprisse a palavra e o projeto de salvação, questão que não é posta no poema.

\section{Considerações finais}

Os poemas de Luiz Augusto Cassas e de Murilo Mendes se prefiguram como expoentes paradigmáticos da influência da Bíblia como matéria-prima da composição literária e do dinamismo das reescrituras literárias. Nesse sentido, observamosduas diferentes formas de incorporação/assimilação de textos da tradição judaico-cristã presente na Bíblia. De um lado, Cassas se apropria dos textos bíblicos em níveis arquitextuais, hipertextuais, intertextuais e interdiscursivos para satirizar alguns sentidos dos Salmos de Davi.Sua paródia é mais canônica, mais perto de um canto que se produz ao lado, mas para satirizar, para contestar. Mas não se trata de mera satirização do poeta. Algumas das figuras introduzidas no jogo de reescritura refletem e refratam ditados populares e conversas do cotidiano das pessoas, em face da vulgarização da pregação de algumas igrejas mercadológicas.

De modo diferente de Cassas, a poesia de Murilo Mendes faz uso do texto bíblico não com a propositura de distendê-lo para visões novas, mas endossa uma interpretação já existente e, ao utilizar intertextual e interdiscursivamente os mitos bíblicos, serve a poesia para fixação de uma interpretação já existente na tradição teológica, no poeta, confessada e explicitamente católica. O que não desmerece o valor de sua poesia em Quatro textos Evangélicos, mas a coloca num lugar muito específico de uma tradição de poetas convertidose que se utilizam do dispositivo poético para a propagação de verdades teológicas da tradição 
da igreja. Sua paródia é mais próxima da séria, daquela que canta ao lado buscando harmonia e reprodução de um discurso. Necessariamente, a poesia de Murilo Mendes não se resume a essa constatação, há várias facetas que fogem ao confessionalismo.

Concluímos,então, que os salmos do Deus Mix de Cassas são configurados metaforicamente e se apresentam como reescriturasparodísticas dos Salmos de Davi, da Bíblia, ao tempo em que assimilam de modo dissonante aspectos da cultura religiosa cristã contemporânea, produzindo sentidos que podem, implicitamente, ser interpretados como uma crítica humorística e carnavalizante a algumas expressões teológicas prevalecentes em religiões mercadológicas. E, em posição oposta, os Quatro textos evangélicos de Mendes se configuram como uma reescritura quase que literal dos textos bíblicos, servindo-se da intertextualidade bíblica para reafirmar e endossar uma interpretação teológica já existente, mas que, em contraponto a Cassas, serve como antítese ao projeto crítico do poeta maranhense. Assim, analisando dois poetas com posturas inventivas tão distintas, exibimos, de modo exemplar, modos distintos de hipertextos, incorporação da Bíblia, transposiçãoe reescritura literária, no âmbito da literatura brasileira.

\section{Referências}

ANDRADE, Carlos Drummond de. Antologia poética. Rio de Janeiro: Record, 2007.

BANDEIRA, Manuel. Estrela da Vida Inteira. Rio de Janeiro: Editora Nova Fronteira, 1993. BRANDÃO, Eli. Literatheos. Campina Grande: Editora Livro Rápido, 2007.

BRANDÃO, Eli. O símbolo na metáfora. In: SILVA, Antonio de Pádua Dias da. (Org.). Literatura e Estudos Culturais. João Pessoa/Campina Grande: UFPB-Editora Universitária/ UEPB-EDUEP, 2004, p. 51-82.

CASSAS, Luís Augusto. Deus Mix: salmos energéticos c/ guaraná \& cassis.Rio de Janeiro: Imago, 2001.

FIORIN, José Luiz. Polifonia textual e discursiva. In: BARROS, Diana Luz Pessoa de. FIORIN, José Luiz(Orgs.). Dialogismo, Polifonia, Intertextualidade. São Paulo: EDUSP, 1999, p. 29-36.

GENETTE, Gérard. Palimpsestos. A literatura de segunda mão. Belo Horizonte: Edições Viva Voz, 2010.

LIMA, Jorge de. Poesia Completa. Volume II. Rio de Janeiro: Nova Aguilar, 1997.

MAINGUENEAU, Dominique. Gênese dos Discursos. Curitiba: Criar Edições LTDA, 2007.

Novas tendências em Análise do Discurso.São Paulo: Editora da Universidade Estadual de Campinas, 1993. 
MENDES, Murilo. Poesia Completa e Prosa (Org.). Luciana Stegagno Picchio. Rio de Janeiro: Nova Aguilar, 1995.

Antologia Poética. São Paulo: Cosac e Naify, 2014.

MOURA, Murilo Marcondes de. As passagens do poeta. In: MENDES, Murilo Mendes. Antologia poética. São Paulo: Cosac e Naify, 2014 (262-272).

RICOEUR, Paul. O Conflito das Interpretações.Rio de Janeiro: Imago, 1978.

SILVA,José Mário da. Mínimas leituras, múltiplos interlúdios. João Pessoa: Ideia, 2002.

Submetido em: 5-10-2019

Aceito em: 7-11-2019 